\title{
A new squat lobster (Crustacea, Anomura, Munididae) from the Pliocene of Monterotondo Marittimo (Tuscany, Italy)
}

\author{
Alessandro Garassino ${ }^{1}$, Giovanni Pasini ${ }^{2 *}$
}

\begin{abstract}
We report a new species of squat lobster from the Pliocene of Monterotondo Marittimo (Grosseto, Tuscany, Italy). The specimens have been assigned to the fossil and extant Munida Leach, 1820, with M. grossetana n. sp. (Munididae Ahyong, Baba, MacPherson \& Poore, 2010). Munida grossetana n. sp. represents the first report for the genus in the Mediterranean area, enlarging the palaeogeographic distribution for the genus.
\end{abstract}

Key words: Crustacea, Decapoda, Anomura, Pliocene, Italy.

Riassunto - Un nuovo galateide (Crustacea, Anomura, Munididae) del Pliocene di Monterotondo Marittimo (Toscana, Italia).

Si segnala una nuova specie di galateide del Pliocene di Monterotondo Marittimo (Grosseto, Toscana, Italia). Gli esemplari sono stati assegnati al genere fossile e vivente Munida Leach, 1820, con M. grossetana n. sp. (Munididae Ahyong, Baba, MacPherson \& Poore, 2010). Munida grossetana $\mathrm{n}$. sp. rappresenta la prima segnalazione del genere nell'area del Mediterraneo, ampliando la distribuzione paleogeografica del genere.

Parole chiave: Crustacea, Decapoda, Anomura, Pliocene, Italia.

\section{INTRODUCTION}

Specimens of Munida grossetana n. sp. were collected from the Pliocene rocks of Monterotondo Marittimo, located in the Grosseto province (Tuscany, Italy) close to

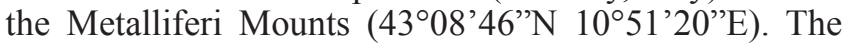
studied specimens, discovered in grey poorly fossiliferous clays, are usually associated with rare small-sized molluscs (mainly bivalves) and irregular echinoids, that are strongly compressed (Schizaster? Pasini pers. comm., 2007). Indeterminate organic material is also present. Deposition

\footnotetext{
Palaeontology Department, Natural History Museum, Corso Venezia 55, 20121 Milano, Italia

E-mail: alessandro.garassino@comune.milano.it; alegarassino@gmail.com

${ }^{2}$ Via Alessandro Volta 16, 22070 Appiano Gentile (CO), Italia

*Corresponding author: juanaldopasini@tiscali.it

(C) 2015 Alessandro Garassino, Giovanni Pasini
}

Received: $6^{\text {th }}$ May 2015

Accepted for publication: $21^{\text {st }}$ May 2015 and its discontinuity indicate an environment characterized by chaotic sedimentation in the presence of more or less wide submarine conoids. Moreover calcareous tubes of the suspension feeder serpulid worm Ditrupa cornea (Linnaeus, 1767), an important component of the muddy benthic community in unstable detrital environments, occur widespread in the muddy-clay marls in small aggregations or as single loose individuals, supporting the presence of a turbiditic environment (Pasini pers. comm., 2007). The marly marine deposits of the studied area are dated to the early-middle Pliocene (Carta Geol. d'Italia., foglio 119, Massa Marittima, 1:100000). We ascribed the studied specimens to the Pliocene sensu lato because of the absence of chronostratigraphic data (Bisconti pers. comm., 2007). De Angeli et al. (1996) reported the brachyurans Raninoides pliocenicus De Angeli, Garassino \& Pasini, 1996; Monodaeus bortolottii Delle Cave, 1988; Goneplax gulderi Bachmayer, 1953; Astenognathus sp. Later, Garassino et al. (2013) also reported Albaidaplax ispalensis Garassino, Pasini \& Castro, 2013.

\section{MATERIALS AND METHODS}

The two studied specimens are three-dimensionally preserved with intact cuticle within a fossiliferous greenish clay. They are assigned to Munida Leach, 1820, with M. grossetana n. sp. (Munididae Ahyong, Baba, MacPherson \& Poore, 2010) and housed in the palaeontological collection of the Museo di Storia Naturale di Milano (MSNM).

Abbreviations: lcxp: carapace length (including rostrum); lr: rostrum length; wcxp: carapace width.

\section{SYSTEMATIC PALAEONTOLOGY}

Infraorder Anomura MacLeay, 1838

Superfamily Galatheoidea Samouelle, 1819

Family Munididae Ahyong, Baba, MacPherson \& Poore, 2010

Genus Munida Leach, 1820

Type species: Pagurus rugosus Fabricius, 1775, by monotypy. 
Fossil species: Munida grossetana $\mathrm{n}$. sp. (this study); M. konara Schweitzer \& Feldmann, 2000; M. nishioi Karasawa, 1993; M. ogaensis (Hatai \& Kotaka, 1970); M. primaeva Segerberg, 1900; M. quadroblonga Schweitzer \& Feldmann, 2000.

\section{Munida grossetana $\mathrm{n} . \mathrm{sp}$.}

Fig. 1

Etymology: The trivial name alludes to Grosseto, regional capital where the fossiliferous locality is located.

Holotype: MSNM i28256.

Paratype: MSNM i28257.

Type locality: Monterotondo Marittimo (Grosseto, Tuscany, Italy).

Geological age: Pliocene sensu lato.

Material and measurements: Two complete carapaces (one without rostrum). MSNM i28256 - lcxp: $5 \mathrm{~mm}$; lr: $2 \mathrm{~mm}$; wcxp: $5 \mathrm{~mm}$; MSNM i28257 - lcxp: $4 \mathrm{~mm}$; wcxp: $4 \mathrm{~mm}$.

Diagnosis: Carapace (excluding rostrum) as long as wide; rostrum slender and spiniform; carapace with transverse striae well spaced; gastric region without epigastric spines; anterolateral margin with one spine; branchial and posterolateral margins smooth.

Description: Carapace (excluding rostrum) as long as

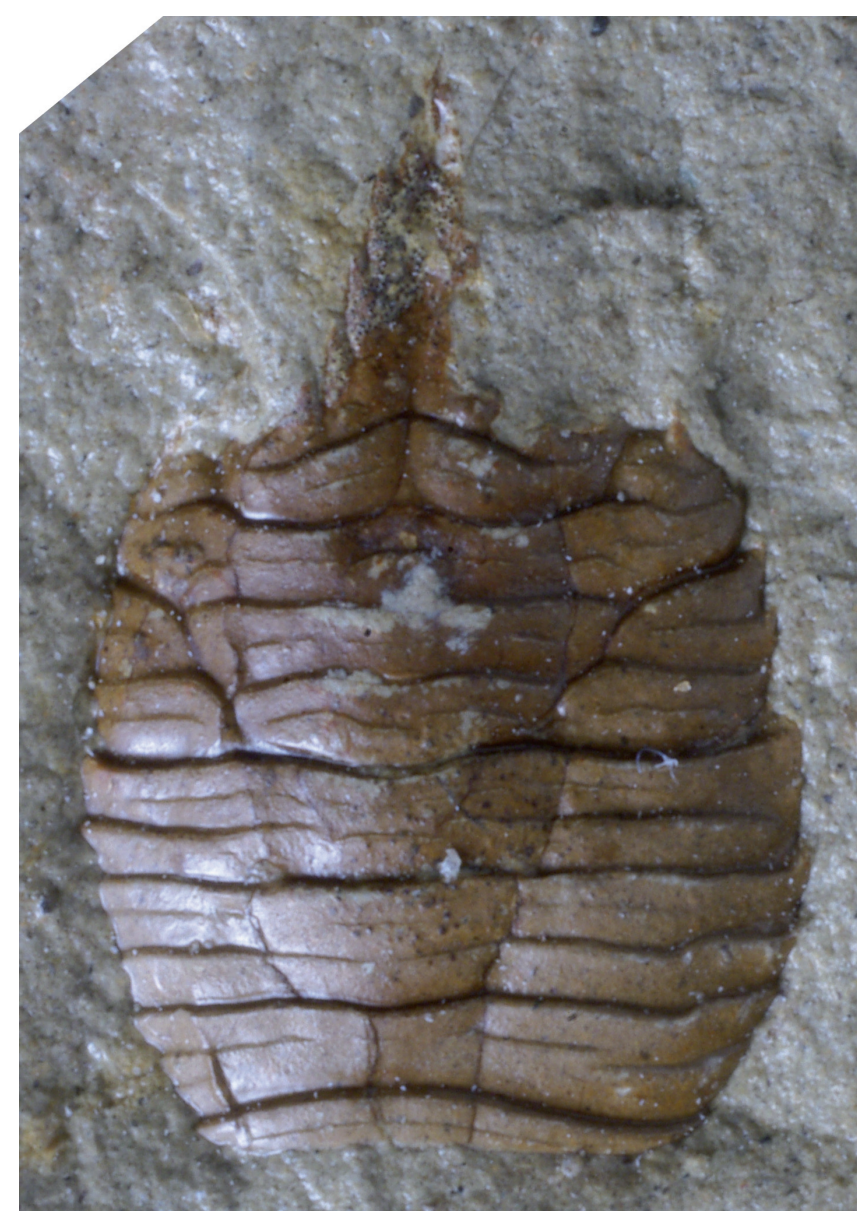

wide, slightly convex laterally; dorsal striae and cervical groove well distinct; gastric region convex and without epigastric spines; epigastric, hepatic, cardiac, intestinal, and branchial regions spineless; all regions with entire transverse striae well spaced, with very few secondary striae; anterior and posterior cervical groove deep; rostrum elongate, dorsally ridged, laterally armed with three spines; supraocular spine small, subparallel, close to rostrum; anterolateral margin with one small anterolateral spine situated at anterolateral angle, not reaching level of sinus between rostrum and supraocular spine; branchial and posterolateral margins smooth.

Discussion: According to Poore (2004) the studied specimens are assigned to the fossil and extant Munida in having carapace with distinct transverse striae, slender spiniform rostrum, and frontal margin of carapace without spine mesiad to anterolateral spine. The studied specimens are further assigned to Munididae Ahyong, Baba, MacPherson \& Poore, 2010, for having a slender spiniform rostrum and for the presence of the supraocular spines. Previously Munida was assigned to Galatheidae Samouelle, 1819, by Schweitzer et al. (2010). However, based upon the recent classification proposed by Ahyong et al. (2010), this genus fits better within the Munididae. Schweitzer et al. (2010) assigned five fossil species to Munida: M. konara Schweitzer \& Feldmann, 2000, from

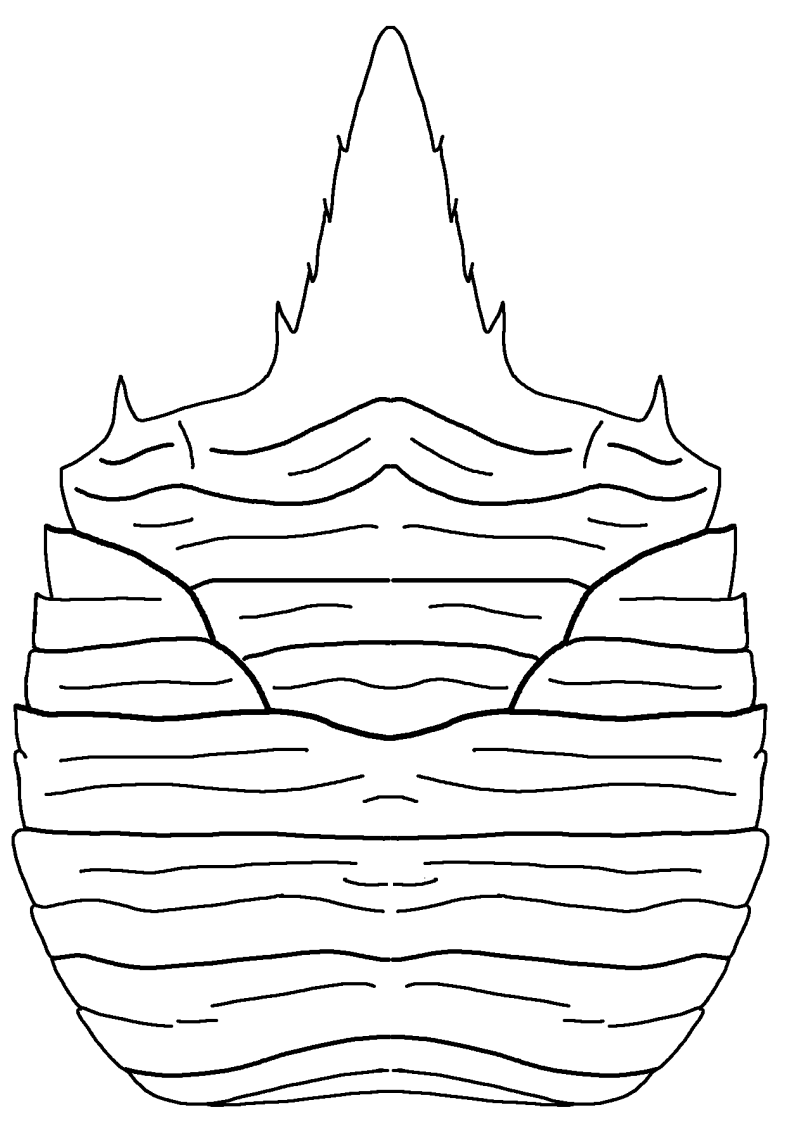

Fig. 1 - Munida grossetana n. sp. A) Holotype, MSNM i28256, dorsal view (×14). B) Idealized reconstruction of dorsal carapace. 
the late Oligocene - early Miocene of Alaska; M. nishioi Karasawa, 1993, from the middle Eocene of Japan; $M$. ogaensis (Hatai \& Kotaka, 1970) from the middle-late Miocene of Japan; M. primaeva Segerberg, 1900, from the Danian of Denmark; M. quadroblonga Schweitzer \& Feldmann, 2000, from the Eocene of Bainbridge Island (WA, United States) (Segerberg, 1900; Hatai \& Kotaka, 1970; Karasawa, 1993; Schweitzer \& Feldmann, 2000).

Based on the main characters of the above-mentioned species, we justify the description of Munida grossetana n. sp. for the rostrum, slender and spiniform with three lateral spines, for one anterolateral spine, and for the branchial and posterolateral margins smooth ( $v s$. rostrum with three spines and three anterolateral spines in $M$. konara; $v s$. lateral margins with six spines in $M$. nishioi; vs. lateral margins with several spines in M. ogaensis; vs. rostrum needle-like and spineless and lateral margins with several spines in $M$. primaeva; vs. rostrum needle-like and spineless, three anterolateral spines, and several posterolateral spines in M. quadroblonga).

Munida grossetana $\mathrm{n}$. sp. represents the youngest record for the genus in the fossil record and the first report of Munida in the Mediterranean area, extending the palaeogeographic distribution for the genus.

\section{Acknowledgements}

We wish to thank the Gruppo Paleontologico C. De Giuli, Castelfiorentino, Firenze, for useful information on Monterotondo outcrop, Rodney M. Feldmann and Hiroaki Karasawa for some reprints, useful to complete the references, making possible the comparison with the studied specimens; Francisco J. Vega, Instituto de Geología, Universidad Nacional Autónoma de México, Coyoacán (Mexico) and Torrey G. Nyborg, Department of Earth and Biological Sciences, Loma Linda University (CA, USA) for careful reviews and criticism.

\section{REFERENCES}

Ahyong S.T., Baba K., MacPherson E. \& Poore G.C.B., 2010 - A new classification of the Galatheoidea (Crustacea: Decapoda: Anomura). Zootaxa, 2676: 57-68.

De Angeli A., Garassino A. \& Pasini G., 1996 - New reports of anomurans and brachyurans from the Cenozoic of Tuscany (Italy). Atti della Società italiana di Scienze naturali e del Museo civico di Storia naturale in Milano, 150 (2): 163-196.

Garassino A., Pasini G. \& Castro P., 2013 - Revision of the fossil species of Goneplax Leach, 1814 (Crustacea, Decapoda, Brachyura, Goneplacidae). Boletín de la Sociadad Geológica Mexicana, 65 (2): 355-368.

Hatai K. \& Kotaka T., 1970 - A problematica from the Nishikurosawa Formation, Oga Peninsula, Akita Prefecture, northeast Honshu, Japan. Saito Ho-on Kai Museum Research Bulletin, 39: 1-5.

Karasawa H., 1993 - Cenozoic Decapod Crustacea from Southwest Japan. Bulletin of the Mizunami Fossil Museum, 29: 1-92.

Poore G.C.B., 2004 - Marine Decapod Crustacea of Southern Australia. A Guide to Identification. Museum Victoria.
Schweitzer C.E. \& Feldmann R.M., 2000 - First notice of the Chirostylidae (Decapoda) in the fossil record and new Tertiary Galatheidae (Decapoda) from the Americas. Bulletin of the Mizunami Fossil Museum, 27: 147-165.

Schweitzer C.E., Feldmann R.M., Garassino A., Karasawa H. \& Schweigert G., 2010 - Systematic list of fossil decapod crustacean species. Crustaceana Monographs, 10: 1-222.

Segerberg K.O., 1900 - De Anomura och Brachyura Dekapoderna inom Skandinaviens Yngre Krita. Geologiska Föreningens i Stockholm Förhandlingar, 22 (5): 347-388. 